Article

\title{
Antiseptic Activity and Phenolic Constituents of the Aerial Parts of Vitex negundo var. cannabifolia
}

\section{Tie-Jun Ling ${ }^{\dagger}$, Wei-Wei Ling ${ }^{\dagger}$, Yuan-Jun Chen, Xiao-Chun Wan, Tao Xia, Xian-Feng Du and Zheng-Zhu Zhang *}

Key Laboratory of Tea Biochemistry and Biotechnology of Ministry of Education and Ministry of Agriculture, Anhui Agricultural University, 130 West Changjiang Road, Hefei 230036, China; E-Mail: ling_tiejun@yahoo.com.cn (T.-J.L.)

$\dagger$ These authors contributed equally to the paper.

* Author to whom correspondence should be addressed; E-Mail: zzz@ahau.edu.cn; Tel.: +86-551-5786765; Fax: +86-551-5786765.

Received: 15 October 2010; in revised form: 11 November 2010 / Accepted: 15 November 2010 / Published: 18 November 2010

\begin{abstract}
Four phenolics, salviaplebeiaside (1), $\gamma$-tocopherol (2), chrysosplenol-D (4), and isovitexin (5), along with $\alpha$-tocoquinone (3) and $\beta$-sitosterol (6) were isolated from the aerial parts of Vitex negundo var. cannabifolia. The isolation was performed using bio-assay tracking experiments. The structures of compounds 1-5 were established by spectroscopic means. The antibacterial activities of the compounds were assessed against Escherichia coli, Bacillus subtilis, Micrococcus tetragenus and Pseudomonas fluorescens. Chrysosplenol-D (4) exhibited activities against all the four spoilage microorganisms.
\end{abstract}

Keywords: Vitex negundo var. cannabifolia; Verbenaceae; phenolics; antibacterial activities; spoilage microorganisms

\section{Introduction}

Vitex negundo var. cannabifolia (Verbenaceae) is a shrub growing mainly in Yangzi River basin of China [1]. The plant was used as herbal medicine for the treatment of many diseases, such as colds, malaria, inflammation, sores and beriberi [2]. Some iridoids, lignans and other components in the 
species were reported in previous phytochemical studies [3-5]. The juice extracted from aerial parts of the plant has been used as a folk antiseptic in Anhui province of China for preventing meat from rotting. In this study, four phenolics (compounds 1, 2, 4 and 5), along with two other compounds (3 and 6), were isolated and identified. Their antibacterial activities were examined and compound 4 was found to exhibit inhibitory activity against the four tested bacterial spp..

\section{Results and Discussion}

\subsection{Antibacterial Activities of the Crude Extracts}

The EtOH extract of the powdered dry aerial parts of $V$. negundo var. cannabifolia was successively fractionated with petroleum ether $(\mathrm{PE}), \mathrm{CHCl}_{3}$ and $n-\mathrm{BuOH}$. The $n$ - $\mathrm{BuOH}$ fraction was further fractionated by Diaion HP-20 column chromatography (CC) using $\mathrm{H}_{2} \mathrm{O}, 50 \% \mathrm{EtOH}$ and $95 \% \mathrm{EtOH}$ in a sequential elution process to yield three fractions A-C.

The antibacterial activities of the EtOH extract, as well as the $\mathrm{PE}, \mathrm{CHCl}_{3}, \mathrm{~B}, \mathrm{C}$ fractions against Escherichia coli, Bacillus subtilis, Micrococcus tetragenus, and Pseudomonas fluorescens were evaluated by the hole plate diffusion method (see Experimental section 3.10 for more details) [6]. The EtOH extract and the four other fractions were individually dissolved and diluted with DMSO to obtain serial concentrations of 100,50 and $25 \mathrm{mg} \cdot \mathrm{mL}^{-1}$. The inhibition activities were evaluated by diameters of the inhibition zones (Figure 1).

Figure 1. Antibacterial activities of the $\mathrm{EtOH}$ extract as well as $\mathrm{PE}, \mathrm{CHCl}_{3}, \mathrm{~B}$ and $\mathrm{C}$ fractions. Data are means $\pm \mathrm{SD}, \mathrm{n}=3$. Within each concentration treatment, columns containing the same letter are not significantly different according to Duncan's new multiple range test at $P<0.05$. [(A) E. coli, (B) B. subtilis, (C) M. tetragenus, (D) $P$. fluorescens].
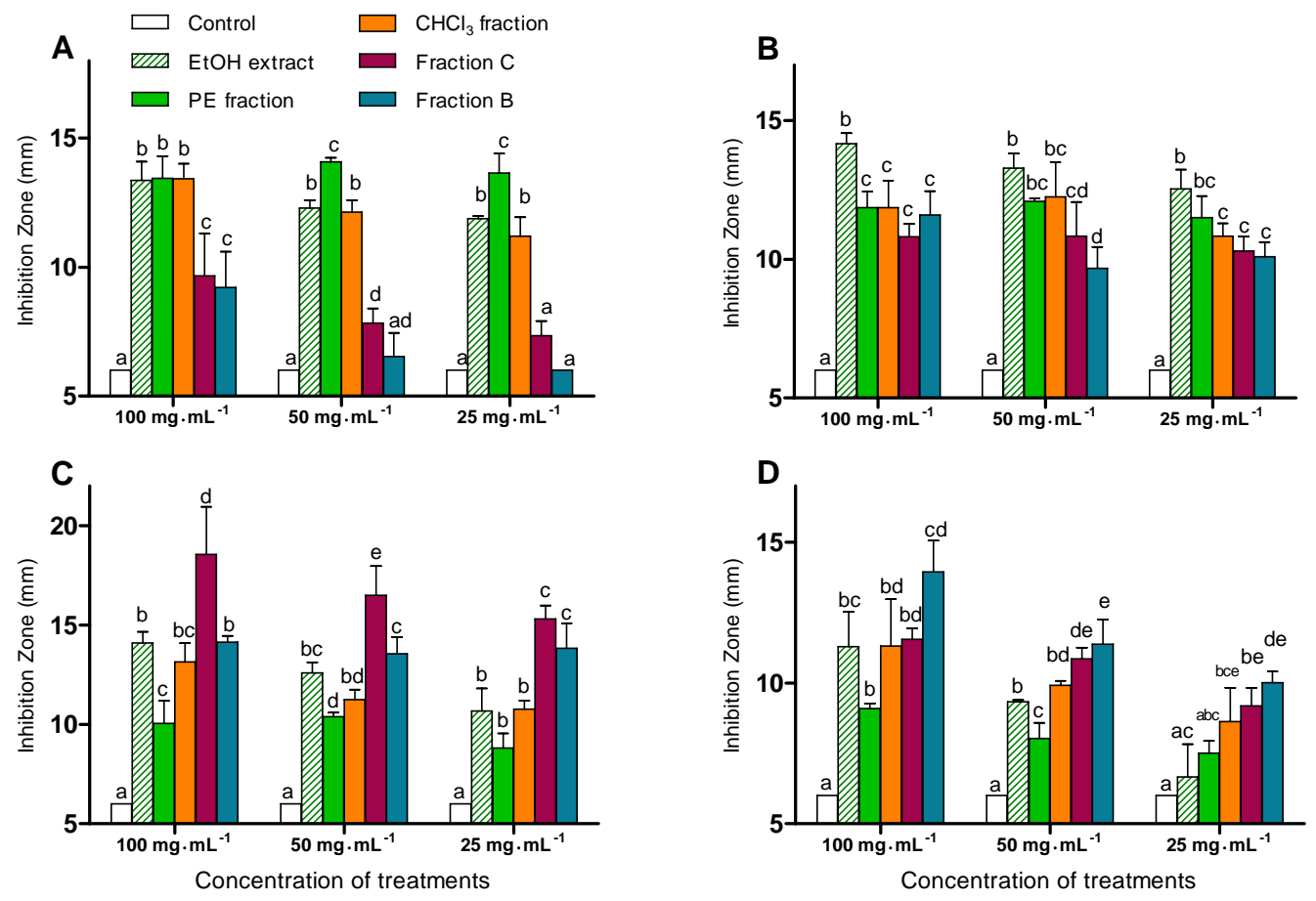
Figures 1A-D show the significant inhibitory activities of the crude extracts at all three tested concentrations. The activity against $E$. coli was enhanced as the polarity of the fractions decreased (Figure 1A), and the PE fraction showed significantly higher activity against $E$. coli at the concentrations of 50 and $25 \mathrm{mg} \cdot \mathrm{mL}^{-1}$ versus the other fractions. However, there was no significant difference in the inhibition activity against B. subtilis among the four fractions (Figure 1B). The activity of fraction $\mathrm{C}$ against $M$. tetragenus was significantly higher than that of any other fraction (Figure 1C). Furthermore, at concentrations 50 and $25 \mathrm{mg} \cdot \mathrm{mL}^{-1}$, both fractions $\mathrm{C}$ and $\mathrm{B}$ showed significantly higher activities compared to the $\mathrm{PE}$ and $\mathrm{CHCl}_{3}$ fractions. In Figure $1 \mathrm{D}$, the inhibitory activities of the fractions against $P$. fluorescens were enhanced with the increase of the fractions' polarity. Both fractions $\mathrm{C}$ and $\mathrm{B}$ displayed higher activities than the $\mathrm{PE}$ or $\mathrm{CHCl}_{3}$ fraction at all three concentrations. Overall fraction $\mathrm{B}$ showed a stronger inhibition against $P$. fluorescens. These results suggest that the bio-active components against $E$. coli were present in the lower-polarity (PE) fraction, while those against $M$. tetragenus and $P$. fluorescens were located in higher-polarity fractions (C and $\mathrm{B})$.

\subsection{Isolation and Identification of the Compounds}

The PE, B and C fractions were presumed to contain bio-active compounds from the results of the above assays, and were therefore separated by a combination of silica gel, ODS-A, and Sephadex LH-20 CC to yield compounds 1-6 (Figure 2).

Compound $\mathbf{1}$ was obtained as a pale yellow gum. Its molecular formula was determined as $\mathrm{C}_{23} \mathrm{H}_{26} \mathrm{O}_{10}$ by the negative HRESI-TOF-MS signal at $\mathrm{m} / \mathrm{z} 461.1462$. The ${ }^{1} \mathrm{H}-,{ }^{13} \mathrm{C}-\mathrm{NMR}$ and HSQC spectra showed the signals of a carbonyl group $\left(\delta_{\mathrm{C}} 211.13\right)$, a tertiary methyl group $\left[\delta_{\mathrm{H}} 2.023(3 \mathrm{H}, \mathrm{s})\right.$, $\left.\delta_{\mathrm{C}} 30.00\right]$, a 1,2,4-trisubstituted benzene $\left[\delta_{\mathrm{H}} 6.933(1 \mathrm{H}, \mathrm{d}, J=8.4 \mathrm{~Hz}), \delta_{\mathrm{H}} 6.574(1 \mathrm{H}\right.$, br s), and $\left.\delta_{\mathrm{H}} 6.284(1 \mathrm{H}, \mathrm{dd}, J=8.4,1.6 \mathrm{~Hz})\right]$, and a $\beta$-D-glucopyranosyl moiety $\left[\delta_{\mathrm{H}} 4.625(1 \mathrm{H}, \mathrm{d}, J=5.2 \mathrm{~Hz})\right.$, $\left.\delta_{\mathrm{C}} 104.30,77.59,75.83,74.88,72.07,64.83\right]$. The high field region of the ${ }^{1} \mathrm{H}-\mathrm{NMR}$ spectrum gave a $4 \mathrm{H}$ singlet $\left(\delta_{\mathrm{H}} 2.617\right)$, which was correlated with two carbon signals at $\delta_{\mathrm{C}} 45.81$ and 30.20 in the HSQC spectrum. The above information was characteristic of a phenylbutanone glucoside, containing a glucopyranosyl moiety, and an aromatic ring (A-ring) with a butanone substituent [7]. The 4H singlet $\left(\mathrm{CH}_{2}-7\right.$ and $\left.\mathrm{CH}_{2}-8\right)$ mentioned above was believed to be the results of the magnetic equivalence of those protons. The ${ }^{1} \mathrm{H}$ - and ${ }^{13} \mathrm{C}$-NMR spectra of $\mathbf{1}$ were very similar to those of vitexfolin $\mathrm{C}$, which hads a $p$-hydroxybenzoyl group (B-ring) at its $2^{\prime}$ position, and by careful comparison of the spectral data of 1 with those of vitexfolin $\mathrm{C}$ [7], the presence of a p-hydroxybenzoyl group $\left[\delta_{\mathrm{H}} 7.753(2 \mathrm{H}, \mathrm{d}\right.$, $J=8.8 \mathrm{~Hz}), \delta_{\mathrm{H}} 6.648(2 \mathrm{H}, \mathrm{d}, J=8.8 \mathrm{~Hz}), \delta_{\mathrm{C}} 168.14\left(\mathrm{C}-7^{\prime \prime}\right), 165.63$ (C-4"), 133.03 (C-2", 6"), 120.95 $\left.\left(\mathrm{C}-1^{\prime \prime}\right), 116.82\left(\mathrm{C}-3^{\prime \prime}, 5^{\prime \prime}\right)\right]$ in $\mathbf{1}$ could indeed be readily deduced. The key differences between the NMR spectra of 1 and those of vitexfolin $\mathrm{C}$ were the chemical shifts of the ${ }^{1} \mathrm{H}$ - and ${ }^{13} \mathrm{C}-\mathrm{NMR}$ signals of the $2^{\prime}, 5^{\prime}$ and $6^{\prime}$ positions. In the NMR spectra of $\mathbf{1}$, the chemical shifts of $\mathrm{H}-2^{\prime}, \mathrm{C}-2^{\prime}$ and $\mathrm{C}-5^{\prime}$ were upshifted to $\delta_{\mathrm{H}} 3.446, \delta_{\mathrm{C}} 74.88$ and $\delta_{\mathrm{C}} 75.83 \mathrm{ppm}$, respectively, while those of H-5', H-6'a, H-6'b and C-6' were downshifted to $\delta_{\mathrm{H}} 3.641, \delta_{\mathrm{H}} 4.575, \delta_{\mathrm{H}} 4.275$, and $\delta_{\mathrm{H}} 64.83 \mathrm{ppm}$, respectively, suggesting that the $\beta$-D-glucopyranosyl moiety in 1 was $1^{\prime}, 6^{\prime}$-disubstituted instead of $1^{\prime}, 2^{\prime}$-disubstituted as in vitexfolin C. By analysis on the reported phenylbutanone glucosides in Vitex spp., 1 was assumed to be a 1'-(A-ring),6'-(B-ring)-disubstituted glucopyranose [7]. The hypothesis was confirmed by analysis of 
the HMBC spectrum, which showed cross peaks between $\mathrm{H}-6^{\prime}\left(\delta_{\mathrm{H}} 4.575\right.$ and $\left.\delta_{\mathrm{H}} 4.275\right)$ and C-7" $\left(\delta_{\mathrm{C}} 168.14\right)$, as well as between $\mathrm{H}-1^{\prime}\left(\delta_{\mathrm{H}} 4.625\right)$ and $\mathrm{C}-4\left(\delta_{\mathrm{C}} 144.99\right)$. On the basis of this evidence, 1 was identified as 4-\{4-O-[6-(4-hydroxybenzoyl)-O- $\beta$-D-glucopyranosyl]-3-hydroxyphenyl $\}$-2-butanone. The structure was previously reported as salviaplebeiaside from Salvia plebeian [8].

By comparison their spectroscopic data (see the Experimental section) with those reported in the references, compounds 2-5 were identified as $\gamma$-tocopherol, $\alpha$-tocoquinone, chrysosplenol-D and isovitexin, respectively [9-12]. Compound $\mathbf{6}$ were identified as $\beta$-sitosterol by comparing its $\mathrm{Rf}$ value with that of an authentic sample in a TLC experiment.

Figure 2. Structures of Compounds 1-5.
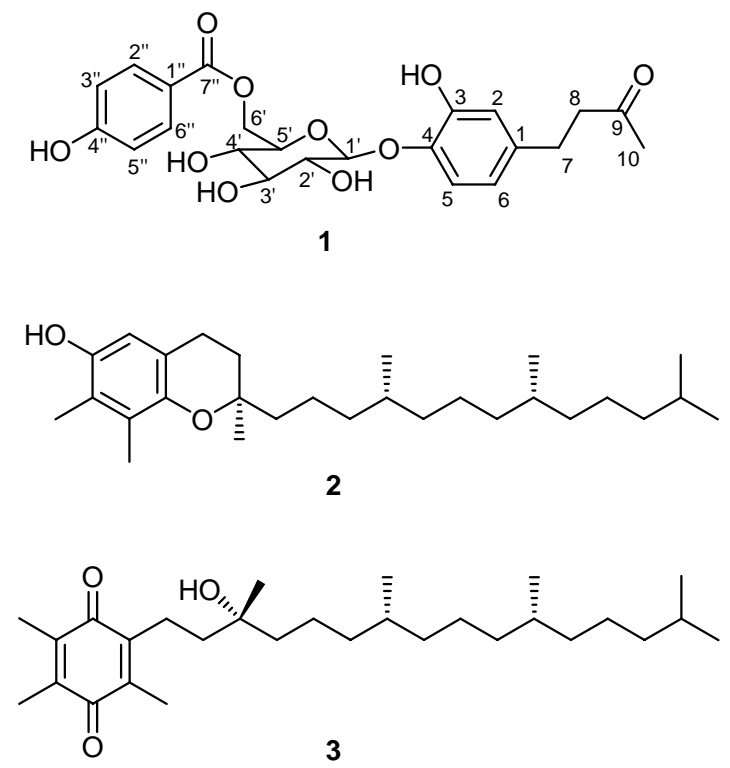<smiles>COc1cc2oc(-c3ccc(O)c(O)c3)c(OC)c(=O)c2c(O)c1OC</smiles>

4

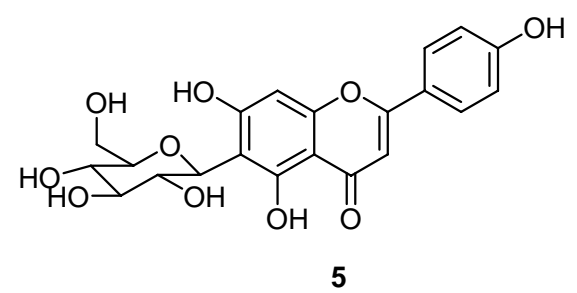

\subsection{Antibacterial Activities of Compounds 1-5}

The antibacterial activities of 1-5 against E. coli, B. subtilis, M. tetragenus, and P. fluorescens were also evaluated by the hole plate diffusion method. Compound 4 exhibited weak activities against $E$. coli, B. subtilis and M. tetragenus, with minimal inhibitory concentration (MIC) values of 500, 500 and $250 \mu \mathrm{g} \cdot \mathrm{mL}^{-1}$, respectively. At the same concentrations, ampicillin sodium displayed much stronger inhibition against the corresponding microorganisms. Nevertheless, the inhibitory activity of $\mathbf{4}$ against P. fluorescens was comparable with that of ampicillin sodium (MIC, $500 \mu \mathrm{g} \cdot \mathrm{mL}^{-1}$, see Table 2).

\section{Experimental}

\subsection{General}

IR spectra were obtained on a Nicolet 8700 FT-IR spectrophotometer (Thermo, USA). The ${ }^{1} \mathrm{H}-\mathrm{NMR}(400 \mathrm{MHz}),{ }^{13} \mathrm{C}-\mathrm{NMR}(100 \mathrm{MHz})$ and 2D-NMR spectra such as HSQC and HMBC were recorded on a Bruker Avance-400 (Bruker, Switzerland). Chemical shifts are expressed in ppm $(\delta)$. The ESI-MS data were obtained with a Finnigan LTQ LC/MS system (Thermo, USA) by direct injection. The HRESI-TOF-MS was recorded on an Agilent 6210 instrument (Agilent Technologies, Inc., USA) by direct injection. Silica gel 60 (200-300 mesh, Qingdao Marine Chemical Co. Ltd., 
Qingdao, PR China) and YMC GEL ODS-A (50 $\mu \mathrm{m}$, YMC Co. Ltd., Japan) were used for CC. MeOH was used as the eluant in Sephadex LH-20 CC. TLC was performed using precoated silica gel plates (GF254, Liangchen Chemical Co. Ltd., Huoshan, Anhui province, PR China), or precoated RP-18 silica gel plates (F254, Merck, Germany), with detection by spraying with $10 \% \mathrm{H}_{2} \mathrm{SO}_{4}$ /ethanol reagent followed by heating.

\subsection{Plant Material}

Aerial parts of $V$. negundo var. cannabifolia were collected in the rural area of Xuan-Cheng, Anhui Province, China, in summer of 2008, and identified by Prof. Sheng-Ni Tian, Anhui Agricultural University, and Prof. Yue-Hong Yan, Hunan University of Science and Technology. A voucher specimen was deposited at the Laboratory of Botany, School of Life Sciences, Anhui Agricultural University.

\subsection{Extraction}

Dry stems and leaves of $V$. negundo var. cannabifolia $(3.0 \mathrm{~kg})$ were ground to a fine powder, which were extracted with $95 \%$ EtOH three times $(24,48$ and $48 \mathrm{~h}$ with $10 \mathrm{~L}$ each time) by percolation at room temperature. The EtOH percolate was concentrated in vacuo to a syrup (EtOH extract, $420 \mathrm{~g}$ ). This syrup was suspended in $\mathrm{H}_{2} \mathrm{O}$ and the aqueous suspension $(1000 \mathrm{~mL}$ ) was successively extracted with $\mathrm{PE}\left(500 \mathrm{~mL}, 3\right.$ times), $\mathrm{CHCl}_{3}(500 \mathrm{~mL}, 3$ times), and $n$ - $\mathrm{BuOH}(500 \mathrm{~mL}, 3$ times) at room temperature. The $\mathrm{PE}$ and the $\mathrm{CHCl}_{3}$ extracts, on concentration, yielded a dark green syrup (PE fraction, $60 \mathrm{~g})$ and a brown syrup $\left(\mathrm{CHCl}_{3}\right.$ fraction, $\left.40 \mathrm{~g}\right)$ respectively. The $n$ - $\mathrm{BuOH}$ extraction, upon concentration under reduced pressure, afforded $90 \mathrm{~g}$ of a brown syrup. This syrup was further fractionated by Diaion $\mathrm{HP}-20 \mathrm{CC}$ using $\mathrm{H}_{2} \mathrm{O}, 50 \% \mathrm{EtOH}$ and $95 \% \mathrm{EtOH}$ in a sequential elution process, yielding three fractions A-C.

\subsection{Isolation of the Compounds}

The PE fraction was subjected to $\mathrm{CC}$ on silica gel, eluted with PE-EtOAc mixtures of increasing polarity (from 15:1 to 8:1), to give three fractions (PE1-PE3). Fraction PE1 was further subjected sequentially to silica gel CC using 99:1 PE-EtOAc as eluant, and to ODS-A CC using methanol as eluant, to afford $2(13 \mathrm{mg}), 3(21 \mathrm{mg})$ and $\mathbf{6}(60 \mathrm{mg})$. Fraction B (53 g) was subjected sequentially to silica gel $\mathrm{CC}$ eluted with $\mathrm{CH}_{2} \mathrm{Cl}_{2}-\mathrm{CH}_{3} \mathrm{OH}$ mixtures of increasing polarities (from 10:1 to 5:1), to ODS-A CC using $\mathrm{CH}_{3} \mathrm{OH}-\mathrm{H}_{2} \mathrm{O}$ (2:3) as eluant, and to Sephadex $\mathrm{LH}-20 \mathrm{CC}$ to afford 1 (27 mg) and 5 $(10 \mathrm{mg})$. Fraction $\mathrm{C}(4 \mathrm{~g})$ was subjected to silica gel $\mathrm{CC}$ eluted with $\mathrm{CH}_{2} \mathrm{Cl}_{2}-\mathrm{MeOH}(10: 1)$ and repeated Sephadex LH-20 CC to yield 4 (24 mg).

\subsection{Salviaplebeiaside (1)}

Pale yellow gum. IR (KBr) $v_{\max }\left(\mathrm{cm}^{-1}\right): 3,420,2,923,1,702,1,609,1,594,1,511,1,448,1,281$, 1,167, 1,073, 882, 852, 800, 772, 729 and 698. HRESI-TOF-MS: $m / z 461.1462[\mathrm{M}-\mathrm{H}]^{-}$(calcd. for $\left.\mathrm{C}_{23} \mathrm{H}_{25} \mathrm{O}_{10}{ }^{-}, 461.1453\right)$ in negative mode. ${ }^{1} \mathrm{H}-$ and ${ }^{13} \mathrm{C}-\mathrm{NMR}$ data, see Table 1. 
Table 1. ${ }^{1} \mathrm{H}$ - and ${ }^{13} \mathrm{C}-\mathrm{NMR}$ data of $\mathbf{1}$ (in methanol- $d_{4}$ ).

\begin{tabular}{|c|c|c|c|c|c|}
\hline Position & $\delta_{\mathrm{H}}(J$ in $\mathrm{Hz})$ & $\delta_{\mathrm{C}}$ & Position & $\delta_{\mathrm{H}}(J$ in $\mathrm{Hz})$ & $\delta_{\mathrm{C}}$ \\
\hline 1 & - & 138.13 & $3^{\prime}$ & $3.446^{b}$ & 77.59 \\
\hline 2 & $6.574 \mathrm{br} \mathrm{s}$ & 117.13 & $4^{\prime}$ & $3.357 \mathrm{~m}$ & 72.07 \\
\hline 3 & - & 148.38 & $5^{\prime}$ & $3.641 \mathrm{~m}$ & 75.83 \\
\hline 4 & - & 144.99 & $6^{\prime} \mathrm{a}$ & $4.575 \mathrm{brd}(11.6)$ & 64.83 \\
\hline 5 & $6.933 \mathrm{~d}(8.4)$ & 118.89 & $6^{\prime} \mathrm{b}$ & $4.275 \mathrm{dd}(11.6,7.6)$ & \\
\hline 6 & $6.284 \mathrm{dd}(8.4,1.6)$ & 120.34 & $1^{\prime \prime}$ & - & 120.95 \\
\hline 7 & $2.617 \mathrm{br} \mathrm{s}^{a}$ & 30.20 & $2^{\prime \prime}$ & $7.753 \mathrm{~d}(8.8)$ & 133.03 \\
\hline 8 & $2.617 \mathrm{br} \mathrm{s}^{a}$ & 45.81 & $3 "$ & $6.648 \mathrm{~d}(8.8)$ & 116.82 \\
\hline 9 & - & 211.13 & $4 "$ & - & 165.63 \\
\hline 10 & $2.023 \mathrm{~s}$ & 30.00 & $5^{\prime \prime}$ & $6.648 \mathrm{~d}(8.8)$ & 116.82 \\
\hline $1^{\prime}$ & $4.625 \mathrm{~d}(5.2)$ & 104.30 & $6 "$ & $7.753 \mathrm{~d}(8.8)$ & 133.03 \\
\hline $2^{\prime}$ & $3.446^{b}$ & 74.88 & $7 "$ & - & 168.14 \\
\hline
\end{tabular}

\section{6. $\gamma$-Tocopherol (2)}

Yellow oil; ESI-MS m/z $417[\mathrm{M}+\mathrm{H}]^{+}, 415[\mathrm{M}-\mathrm{H}]^{-} ;{ }^{1} \mathrm{H}-\mathrm{NMR}\left(\mathrm{CDCl}_{3}\right) \delta: 6.372(1 \mathrm{H}, \mathrm{s}, \mathrm{H}-5)$, 2.669 (2H, m, H-4), 2.136, 2.113 (each 3H, s, H-7a, 8a), 1.243 (3H, s, H-2a), 0.872-0.846 (12H, m, H$\left.4^{\prime} \mathrm{a}, 8^{\prime} \mathrm{a}, 12^{\prime} \mathrm{a}, 13^{\prime}\right) ;{ }^{13} \mathrm{C}-\mathrm{NMR}\left(\mathrm{CDCl}_{3}\right) \delta: 146.3(\mathrm{C}-6), 145.9$ (C-8a), $125.9(\mathrm{C}-8), 121.7$ (C-7), $118.4(\mathrm{C}-$ 4a), 112.3 (C-5), 75.6 (C-2), 40.2 (C-1'), 39.5 (C-11'), 37.5 (C-3', 5', 7', 9'), 32.9 (C-4', 8'), 31.6 (C-3), 28.0 (C-12'), 24.9 (C-10'), 24.5 (C-6'), 24.2 (C-2a), 22.8 and 22.7 (C-12'a and C-13'), 22.4 (C-4), 21.1 (C-2'), 19.8 (C-4'a, 8'a), 11.9 (C-7a, 8a).

\section{7. $\alpha$-Tocoquinone (3)}

Yellow oil; ESI-MS m/z $447[\mathrm{M}+\mathrm{H}]^{+}, 445[\mathrm{M}-\mathrm{H}]^{-} ;{ }^{1} \mathrm{H}-\mathrm{NMR}\left(\mathrm{CDCl}_{3}\right) \delta: 2.539$ (2H, m, H-1'), $2.032(3 \mathrm{H}, \mathrm{s}, \mathrm{H}-3 \mathrm{a}), 2.003$ (6H, s, H-2a, 5a), 1.228 (3H, s, H-3'a), 0.867-0.830 (12H, m, H-4'a, 8'a, 12'a, 13'); ${ }^{13} \mathrm{C}-\mathrm{NMR}\left(\mathrm{CDCl}_{3}\right) \delta: 187.8$ (C-4), 187.3 (C-1), 144.5 (C-6), 140.6 (C-5), 140.5 (C-3), 140.3 (C-2), 72.8 (C-3'), 42.4 (C-4'), 40.3 (C-2'), 39.4 (C-14'), 37.7 (C-6'), 37.5 (C-10'), 37.4 (C-12'), 32.7 (C-7', 11'), 29.7 (C-8'), 27.9 (C-15'), 26.7 (Me-3'), 24.9 (C-13'), 24.6 (C-9'), 22.8 (Me-15'), 22.7 (Me15'), 21.5 (C-1'), 21.4 (C-5'), 19.8 (Me-7', 11'), 12.5 (Me-2), 12.4 (Me-2), 11.9 (Me-5).

\subsection{Chrysosplenol-D (4)}

Yellow amorphous powder; ESI-MS $m / z 361[\mathrm{M}+\mathrm{H}]^{+}, 383[\mathrm{M}+\mathrm{Na}]^{+}, 359[\mathrm{M}-\mathrm{H}]^{-}$; ${ }^{1} \mathrm{H}-\mathrm{NMR}$ $\left(\mathrm{DMSO}_{-} d_{6}\right) \delta: 7.56\left(1 \mathrm{H}, \mathrm{d}, J=2.1 \mathrm{~Hz}, \mathrm{H}-2^{\prime}\right), 7.45\left(1 \mathrm{H}, \mathrm{dd}, J=8.4,2.1 \mathrm{~Hz}, \mathrm{H}-6{ }^{\prime}\right), 6.91(1 \mathrm{H}, \mathrm{d}$, $J=8.4 \mathrm{~Hz}, \mathrm{H}-5$ '), $6.80(1 \mathrm{H}, \mathrm{s}, \mathrm{H}-8), 3.93\left(3 \mathrm{H}, \mathrm{s}, 7-\mathrm{OCH}_{3}\right), 3.81\left(3 \mathrm{H}, \mathrm{s}, 3-\mathrm{OCH}_{3}\right), 3.76\left(3 \mathrm{H}, \mathrm{s}, 6-\mathrm{OCH}_{3}\right)$;

${ }^{13} \mathrm{C}-\mathrm{NMR}\left(\mathrm{DMSO}-d_{6}\right) \delta$ : 178.1 (C-4), 158.5 (C-7), 156.0 (C-9), 151.7 (C-5), 151.5 (C-2), 149.3 (C-4'), 145.4 (C-3'), 137.6 (C-3), 131.5 (C-6), 120.6 (C-1'), 120.3 (C-6'), 115.7 (C-2'), 115.3 (C-5'), 105.5 (C10), $91.2(\mathrm{C}-8), 60.0,59.6 .3\left(6,3-\mathrm{OCH}_{3}\right), 56.4\left(7-\mathrm{OCH}_{3}\right)$.

\subsection{Isovitexin (5)}

Yellow amorphous powder; ESI-MS $m / z 455[\mathrm{M}+\mathrm{Na}]^{+}, 431[\mathrm{M}-\mathrm{H}]^{-} ;{ }^{1} \mathrm{H}-\mathrm{NMR}\left(\mathrm{CD}_{3} \mathrm{OD}\right) \delta$ : 7.71 $\left(2 \mathrm{H}, \mathrm{d}, J=8.8 \mathrm{~Hz}, \mathrm{H}-2^{\prime}, 6^{\prime}\right), 6.81\left(2 \mathrm{H}, \mathrm{d}, J=8.8 \mathrm{~Hz}, \mathrm{H}-3^{\prime}, 5^{\prime}\right), 6.47$ (1H, s, H-8), 6.38 (1H, s, H-3), 4.81 
$(1 \mathrm{H}, \mathrm{d}, J=10 \mathrm{~Hz}, \mathrm{H}-1 "), 4.07$ (1H, dd, $J=9.6,9.2 \mathrm{~Hz}, \mathrm{H}-2 "), 3.78$ (1H, dd, $J=12.0,2.0 \mathrm{~Hz}, \mathrm{H}-6 " \mathrm{a})$, 3.65 (1H, dd, $J=12.0,5.2 \mathrm{~Hz}, \mathrm{H}-6 " \mathrm{~b}), 3.40-3.29$ (3H, m, H-3", 4", 5"); ${ }^{13} \mathrm{C}-\mathrm{NMR}\left(\mathrm{CD}_{3} \mathrm{OD}\right) \delta: 184.0$ (C-4), 166.2 (C-2), 165.0 (C-7), 162.8 (C-4'), 162.0 (C-5), 158.7 (C-9), 129.4 (C-2', 6'), 123.1 (C-1'), 117.0 (C-3', 5'), 109.2 (C-6), 105.2 (C-10), 103.9 (C-3), 95.3 (C-8), 82.6 (C-5"), 80.2 (C-3"), 75.3 (C1"), 72.6 (C-2"), 71.8 (C-4"), 62.9 (C-6").

\subsection{Anti-bacterial Assays of the Crude Extracts}

Anti-bacterial activities were evaluated by the hole plate diffusion method [6]. The test microorganisms were E. coli, B. subtilis, M. tetragenus, and P. fluorescens, which were obtained from the School of Basic Medical Sciences, Anhui Medical University, Hefei, P.R. China. The EtOH extract, $\mathrm{PE}$ and $\mathrm{CHCl}_{3}$ fractions, as well as fractions $\mathrm{B}$ and $\mathrm{C}$ were individually dissolved and diluted with DMSO to obtain serial concentrations of 100,50 and $25 \mathrm{mg} \cdot \mathrm{mL}^{-1}$. Six $\mathrm{mm}$ wide holes were bored with a sterilized steel borer into the Nutrient Agar Media (beef extract $3 \mathrm{~g}$, peptone $10 \mathrm{~g}$, agar $17 \mathrm{~g}, \mathrm{NaCl}$ $5 \mathrm{~g}, \mathrm{H}_{2} \mathrm{O}$ 1,000 mL, $\mathrm{pH}$ 7.2) in the Petri dish inoculated with the test microorganism. The solution of the compound $(60 \mu \mathrm{L})$ at a specific concentration was added into each of the holes. DMSO was used as the negative control. The plates were then incubated at $37^{\circ} \mathrm{C}$ for 24 hours. The diameters of the inhibition zones were measured and recorded. The assays were performed three times in order to guarantee reproducibility of results (see Figure 1).

\subsection{Anti-bacterial Assays of the Compounds}

Compounds 1-5 and ampicillin sodium (positive control) were individually dissolved and diluted with DMSO to obtain serial concentrations of $1000,500,250,125$ and $62.5 \mu \mathrm{g} \cdot \mathrm{mL}^{-1}$ (for ampicillin sodium, the solutions were serially diluted from 1000 to $0.03 \mu \mathrm{g} \cdot \mathrm{mL}^{-1}$ ). The anti-bacterial assays were also performed by the hole plate diffusion method as described above. The inhibition zones around the holes were measured and the MIC, which was defined as the lowest concentration being able to inhibit any visible bacterial growth, was recorded. The assays were performed three times for statistical analysis (see Table 2).

\subsection{Statistical Analysis}

The data in Figure 1 are presented as means \pm SD. The values were evaluated by one-way analysis of variance (ANOVA), followed by Duncan's multiple range tests using GraphPad Prism 5.0 software (GraphPad Software Inc., San Diego, CA, USA). Differences were considered significant at $P<0.05$.

Table 2. Antibacterial Activities of Compounds 1-5.

\begin{tabular}{|c|c|c|c|c|}
\hline \multirow{2}{*}{ Compd. } & \multicolumn{4}{|c|}{$\operatorname{MIC}\left(\mu \mathrm{g} \cdot \mathrm{mL}^{-1}\right)^{a}$} \\
\hline & E. coli & B. subtilis & M. tetragenus & P.fluorescens \\
\hline 1 & $>1000$ & $>1000$ & $>1000$ & $>1000$ \\
\hline 2 & $>1000$ & $>1000$ & $>1000$ & $>1000$ \\
\hline 3 & $>1000$ & $>1000$ & $>1000$ & $>1000$ \\
\hline 4 & 500 & 500 & 250 & 500 \\
\hline 5 & $>1000$ & $>1000$ & $>1000$ & $>1000$ \\
\hline $\mathrm{AMP}^{b}$ & 0.122 & 0.061 & 0.244 & 250 \\
\hline
\end{tabular}

${ }^{a}:$ The results were the average of three readings; ${ }^{b}$ : ampicillin sodium. 


\section{Conclusions}

This is the first report on the isolation of salviaplebeiaside, $\gamma$-tocopherol and $\alpha$-tocoquinone from the genus Vitex. Compounds 1-5 were reported from investigated species for the first time. The apoptosisinducing and antimalarial activities, as well as vascular relaxation effects of $\mathbf{4}$ had been reported [13-16]. With respect to antibacterial activities, the inhibition effects of $\mathbf{4}$ on Staphylococcus aureus, Cladosporium cucumerinum and Bacillus cereus were documented [11,17]. Our study indicated the inhibition activities of $\mathbf{4}$ on four spoilage microorganisms for the first time. It is known that $P$. fluorescens plays an important role in rotting of meat. The results of the present assays suggest chrysosplenol-D could be used as a potential antiseptic food additive. Furthermore, this compound might also be one of the key components to account for the medicinal usage of the plant.

In our previous work, the compositions of the essential oil from the aerial parts of $V$. negundo var. cannabifolia and their antiseptic activities were analyzed [18]. However, neither the essential oil, nor the compounds isolated from the PE fraction displayed any significant inhibitory activity against $P$. fluorescens.

A characteristic of phenolic-rich high-polar fraction in the fruits of the investigated species was revealed by previous phytochemical studies [5]. Our work also revealed that phenolics were the predominant components in the high-polar fraction of the aerial parts of the plant. As the high-polar fraction was confirmed as the significant antiseptic fraction by our bio-assays, the phenolics could be the key antiseptic constituents of $V$. negundo var. cannabifolia, even though more chemical examinations have to be done for this plant.

\section{Acknowledgements}

We are grateful to Guang-Hong Liu, Hua-Shi Furnishing Inc., Xuan-Cheng, Anhui Province, for collecting the plant material, and for partial financial support. We also thank Shu Wei, Anhui Agricultural University, for providing advice for the paper, and Yu-Sang Wang, University of Science and Technology of China, Chinese Academy of Sciences, for NMR measurements, and Hua-Rong Tan, Biotechnology Center of Anhui Agricultural University, for ESI-MS measurements, as well as FengLin $\mathrm{Hu}$, School of Forestry \& Landscape Architecture, Anhui Agricultural University, for HRESITOF-MS measurements. This work was supported by Outstanding Youth Foundation of Anhui Province (No. 08040106804), and Starting Foundation for Young Talents of Anhui Agricultural University (2005).

\section{References and Notes}

1. Pei, J.; Chen, S.L. Flora Reipublicae Popularis Sinicae; Science Press: Beijing, China, 1982; Tomus 65 (1), pp. 143-145.

2. Xiao, P.G. Modern Chinese Materia Medica, 1st ed.; Chemical Industry Press: Beijing, China, 2002; pp. 453-457.

3. Taguchi, H. Studies on the constituents of Vitex cannabifolia. Chem. Pharm. Bull. 1976, 24, 1668-1670.

4. Iwagawa, T.; Nakahara, A.; Nakatani, M. Iridoids from Vitex cannabifolia. Phytochemistry 1993, $32,453-454$. 
5. Yamasaki, T.; Kawabata, T.; Masuoka, C.; Kinjo, J.; Ikeda, T.; Nohara, T.; Ono, M. Two new lignan glucosides from the fruit of Vitex cannabifolia. J. Nat. Med. 2008, 62, 47-51.

6. Feng, N.; Ye, W.H.; Wu, P.; Huang, Y.C.; Xie, H.H.; Wei, X.Y. Two new antifungal alkaloids produced by Streptoverticillium morookaense. J. Antibiot. 2007, 60, 179-183.

7. Okuyama, E.; Fujimori, S.; Yamazaki, M.; Deyama, T. Pharmacologically active components of Viticis Fructus (Vitex rotundifolia). II. The components having analgesic effects. Chem. Pharm. Bull. 1998, 46, 655-662.

8. Jin, Q.H.; Han, X.H.; Hwang, J.H.; Hong, S.S.; Park, M.O.; Lee, C.; Lee, C.H.; Lee, D.H.; Lee, M.K.; Hwang, B.Y. A new phenylbutanone glucoside from Salvia plebeian. Nat. Prod. Sci. 2009, 15, 106-109.

9. Matsuo, M.; Urano, S. ${ }^{13} \mathrm{C}$ NMR spectra of tocopherols and 2,2-dimethylchromanols. Tetrahedron 1976, 32, 229-231.

10. Du, G.S.; Cai, X.H.; Shang, J.H.; Luo, X.D. Non-alkaline constituents from the leaf of Alstonia scholaris. Chin. J. Nat. Med. 2007, 5, 259-262. (In Chinese).

11. Wang, Y.; Hamburger, M.; Gueho, J.; Hostettmann, K. Antimicrobial flavonoids from Psiadia trinervia and their methylated and acetylated derivatives. Phytochemistry 1989, 28, 2323-2327.

12. Ramarathnam, N.; Osawa, T.; Namiki, M.; Kawakishi, S. Chemical studies on novel rice hull antioxidants. 2. Identification of isovitexin, a C-glycosyl flavonoid. J. Agr. Food Chem. 1989, 37, 316-319.

13. Arisawa, M.; Hayashi, T.; Shimizu, M.; Morita, N.; Bai, H.; Kuze, S.; Ito, Y. Isolation and cytotoxicity of two new flavonoids from Chrysosplenium grayanum and related flavonols. $J$. Nat. Prod. 1991, 54, 898-901.

14. Li, W.X.; Cui, C.B.; Cai, B.; Wang, H.Y.; Yao, X.S. Flavonoids from Vitex trifolia L. inhibit cell cycle progression at $\mathrm{G}_{2} / \mathrm{M}$ phase and induce apoptosis in mammalian cancer cells. J. Asian Nat. Prod. Res. 2005, 7, 615-626.

15. Chen Liu, K.C.S.; Yang, S.L.; Roberts, M.F.; Elford, B.C.; Phillipson, J.D. Antimalarial activity of Artemisia annua flavonoids from whole plants and cell cultures. Plant Cell Rep. 1992, 11, 637-640.

16. Okuyama, E.; Suzumura, K.; Yamazaki, M. Pharmacologically active components of Viticis Fructus (Vitex rotundifolia). I. The components having vascular relaxation effects. Nat. Med. (Tokyo) 1998, 52, 218-225.

17. Stermitz, F.R.; Scriven, L.N.; Tegos, G.; Lewis, K. Two flavonols from Artemisia annua which potentiate the activity of Berberine and Norfloxacin against a resistant strain of Staphylococcus aureus. Planta Med. 2002, 68, 1140-1141.

18. Ling, W.W.; Zhang, Z.Z.; Ling, T.J.; Zhang, Y.G. Constituents in the essential Oil of Vitex negundo Linn. var. cannabifolia (Sieb.et Zucc.) Hand.-Mazz. and their antibacterial activities. Sci. Technol. Food Ind. 2010, in press. (In Chinese).

Sample Availability: Samples of the compounds 1-6 are available from the authors.

(C) 2010 by the authors; licensee MDPI, Basel, Switzerland. This article is an open access article distributed under the terms and conditions of the Creative Commons Attribution license (http://creativecommons.org/licenses/by/3.0/). 